\title{
COMMENTS
}

\section{ADMINISTRATION OF THE AFFIRMATIVE TRAP AND THE DOCTRINE OF ENTRAPMENT: DEVICE AND DEFENSE†}

The affirmative trap-police solicitation to commit crimeis a widely used detection device in the enforcement of sumptuary criminal laws, particularly those dealing with narcotics. In response to abuse of the device, Illinois courts, and recently the Illinois legislature, have recognized the defense of entrapment. An examination of the decisions of the Illinois Supreme Court reveals that the scope of the defense in Illinois is narrow. Administrative practices of the Narcotics Section of the Chicago Police Department show that the principal police decision that is made in the administration of the device of the affirmative trap is not what inducements to offer, but whether to lay the affirmative trap at all. Field research into the administrative practices of the Cook County State's Attorney's Office reveal marked official insensitivity to the defense. On the basis of an analysis of the interaction of appellate doctrine and administrative practices the author makes recommendations to increase police safeguards in the use of the device and prosecutor sensitivity to the defense. New standards for the scope of the defense are proposed for legislative action.

The affirmative trap ${ }^{1}$ is used primarily in the enforcement of sumptuary legislation proscribing behavior directed against the general welfare rather than against any particular individual.2 Violation of these laws

† David P. Bancroft, J.D. the University of Chicago, 1963; General Legal Assistant, United States Department of Justice, Criminal Division, Organized Crime and Racketeering Section. An earlier draft of this paper was prepared for Visiting Professor Harold S. Solomon's Seminar on Public Prosecution given in the winter and spring quarters of the academic year 1962-63. The author is indebted to members of the Narcotics Section of the Chicago Police Department and the State's Attorney's Office of Cook County for their patience and cooperation in freely giving of their time and energy. The views expressed in this comment are entirely those of the author.

1 There is no generally applied neutral term to describe the device. A neutral term used by police officials to describe official solicitation of narcotics sales offenses is the "controlled" or "supervised" "buy" or "purchase." Compare the term "encouragement" used in Rotenberg, The Police Detection Practice of Encouragement, 49 VA. L. REv. 871 (1963). The phrase "affirmative trap," or more simply, "trap" is used throughout to describe the device.

2 Donnelly, Judicial Control of Informants, Spies, Stool Pigeons, and Agent 
involves willing participants performing consensual acts, the "victims" enjoying themselves. ${ }^{3}$ Since a large portion of the citizenry condones such behavior as falling within the exclusive jurisdiction of the individual's private discretion, and others wish to avoid the social stigma or status degradation which would reflect upon them were they to accuse those close to them, law enforcement is rarely afforded the advantage of a complaining victim or witness. ${ }^{4}$ Finally, these offenses are committed with at least the customary secrecy attendant most other criminal behavior..$^{5}$

Despite the fact that violation of sumptuary laws is not thought by the "victim," those close to him or a large portion of the citizenry to wring a deprivation for which a claim for restoration by the criminal process should be made, it is undeniable that such laws are popular laws. They are popular with the police because among other factors they lead them into areas where the incidence of crime generally is believed to

Provocateurs, 60 YALE L.J. 1091, 1093 (1957). Such sumptuary legislation is made up for the most part of laws dealing with sexual offenses, liquor, narcotics, gambling and abortion.

3 Model Penal Code $\S 2.10$, comment 2 (Tent. Draft No. 9, 1959). Doubts about including "willing victim" conduct within the scope of the criminal law have been ably expressed in Allen, The Borderline of the Criminal Law: Problems of "Socializing" Criminal Justice, 32 Soc. SERvige REv. 107 (1958).

4 In an address before the New York County Grand Jury Association in 1947, the District Attorney for New York County, New York, Frank S. Hogan said: "We appear to have developed a public morality which condemns-rather than praises-any private citizen who seeks to enforce the laws that we-as members of a free society-have called into being." Quoted in HARNex \& CRoss, THE INFORMER IN LAW ENFORCEMENT 6-7 (1960). See also People v. Outten, 13 Ill. 2d 21, 24, 147 N.E.2d 284, 286 (1958): "Resort to such practices [the affirmative trap] to enforce the law and punish its violation becomes necessary 'in view of the well-known facts that criminals usually work in secrecy and that some unlawful practices are encouraged and protected by a large class of citizens." Recent efforts in New York to combat the "reluctance to tell" problem have centered on Mayor Wagner's "Box 100" program. N.Y. Times, Aug. 20, 1963, p. 24, col. 2: "Complaints sent by citizens to Mayor Wagner's Box 100, New York 8 , have resulted in more than 5,000 arrests by the police since the box was set up in January, 1961. This figure was announced yesterday by the Mayor, who said the arrests were for a variety of major offenses, including narcotics, prostitution and gambling." The identity of a citizen who sends a complaint to "Box 100 " is protected.

5 Although these offenses characteristically involve a "course of dealing," they are difficult to spot by standard patrol techniques for that very reason. They are in many respects indistinguishable from legitimate transactions. Their commission is usually swift and surrounded by precautionary measures initially motivated by distrust of the "regular customers" but which also operate against detection by the police. For example, it was reported by the Chicago Narcotics Section that street pushers sometimes secrete narcotics in the body crevices to avoid the possibility of a "big loss" if they are "rolled," and this insurance means that delivery must be made in an interior or comparatively private location difficult to detect by standard patrol techniques. See People v. McSmith, 23 Ill. 2d 87, 92-94, 178 N.E.2d 641, 643-45 (1961); People v. Strong, 21 Ill. 2d 320, 325, 172 N.E.2d 765, 766 (1961); People v. Outten, 13 Ill. 2d 21, 22-23, 147 N.E.2d 284, 286 (1958). 
be high, ${ }^{6}$ the detection work is interesting, invariably involving "secret" efforts in elite police units, and the substantive nature of the offenses is endowed with a certain morbid flavor. They are popular with the prosecutor because the cases are routine, provide a good training ground for the younger state's attorneys, and are unlikely to compel any compromises with private ambitions. They are popular with juries ${ }^{7}$ because of their notions about the nature and consequences of the crimes, ${ }^{8}$ and may even be popular with judges because they are enforced primarily against those who characteristically exert little political influence. ${ }^{9}$

Because a demand is made against the criminal process to enforce laws

- Police perception of the addict crime problem differs from this general belief. See page 158 infra. Compare note 79 infra.

7 The available statistics on the matter, taken from PETERson, A REPort on Chicago CRIME 28 (1961); id. at 18 (1962); id. at 9 (1963), are revealing:

JURY TRIALS OF NARCOTICS CASES

\begin{tabular}{lccc}
\hline & No. of Cases & Guilty & Not Guilty \\
\hline 1960 & 21 & 20 & 1 \\
1961 & 17 & 12 & 5 \\
1962 & 18 & 17 & 1 \\
\hline
\end{tabular}

The increase in "not guilty" verdicts has an interesting background. The Cook County State's Attorney's office explained that due in large part to the success achieved in the prosecution of narcotics cases in 1960 the office instituted a policy of "full prosecution" (maximum charging) against narcotics offenders. The plan backfired. Since the trial judges were reluctant to invoke the high minimum penalties provided by statute they directed several not guilty verdicts in the face of prosecutor refusal to reduce the charge. .

8 The culpability of the narcotics offender is said to be based on a number of notions: "Narcotics ravage the human body." "Narcotics destroy morality." "Narcotic addicts are a sexual menace." "Drug use makes a weak, ineffective member of society." "Narcotic addicts are criminals." "Addiction is contagious." "Once an addict always an addict." Eldridge, NARcotics aND THE LAW 13-34 (1962). The author calls these notions into question. See also Solomon, Book Review, 30 U. CHr. L. REv. 794 (1963). The definite strain of "middle class morality" that often shows up in jury deliberations has not gone unnoticed by defense counsel: "[I]f I had to make a generalization about a single kind of person I think a defense lawyer ought to avoid as a juror, I would say stay away from the personality representing petty respectability. The top sergeants,' or noncommissioned officers of big business; the foreman at the gas company; the teller at the bank; the floor-walker at the big department store. They are all unduly responsive to the pressures of 'respectability' in the community, and they are rarely very likely to listen to a defense with any great sympathy." Steinberg \&. Paulsen, $A$ Conversation with Defense Counsel on Problems of a Criminal Defense, 7 Prac. Law., May 1961, pp. 25, 26.

9 A Cook County State's Attorney pointed out an example. He cited a case in which the government informer supplied the narcotics purchased from the defendant. The trial judge who was, according to the prosecutor, ardently seeking election, imposed a severe sentence. The prosecutor had recommended the minimum ten years. 
whose breach rarely affords the police complaining victims or witnesses a tension is created: A claim is made on enforcement agencies which cannot be satisfied by standard police techniques. In order to successfully apprehend violators the police need to be present at the time and place the crime is committed. But omnipresence is not a realistic expectation. Behavior offensive to such legislation is likely to be widely dispersed. Time and personnel limitations, largely functions of budgetary considerations, call for selective enforcement in the form of spot control.10

It is to resolve this tension between the demand for enforcement of sumptuary legislation and the difficulties in securing notice and evidence of willing "victim" crimes that the device of the affirmative trap is used. Characteristically an informer-purchaser and a police undercover agent approach a suspect with an offer to purchase an illegal commodity. Insofar as the device is sanctioned by the courts, it is an exceptional one. Official solicitation and participation in the criminal act is condoned. In every case the defendant could not have committed the particular act for which he is tried without the opportunity and facilities furnished by law enforcement officials. Such an enforcement procedure can only be justified on the questionable assumption, inimical to the aim of deterrence, that affirmative conduct on the part of the state in encouraging a particular offense that otherwise would not have been committed is necessary to incarcerate those who, because they once committed crime with police solicitation, have committed or will commit similar crimes that escape police detection.

As the affirmative trap is used to overcome difficulties in the detection of secret criminal acts and apprehension of their willing "victims," it is companion to two other police devices used to similar ends: surveillance and harassment.

Police surveillance involves the constant observance of suspicious conduct not only in an undercover capacity by men with eyes and ears, but perhaps more typically by the use of sophisticated scientific devices, such as high-powered binoculars, telephotography, infrared searchlights, detectaphones, "bugs" and closed television circuits. ${ }^{11}$ Like the affirmative trap, police surveillance involves a crucial prudential judgment equally open to question: That police acquiescence in the commission or attempted commission of an offense, which might otherwise not have been committed if police presence and authority were known and felt, is

10 Goldstein, Police Discretion Not to Invoke the Criminal Process: Low Visibility Decisions in the Administration of Justice, 69 YALE L.J. 545, 560 (1960).

11 See O'Hara, Fundamentals of Criminal Investigation (1956). Dash, Schwartz \& Knowlton, The Eavesdroppers (1959), contains (in Part Two-Eavesdropping: The Tools) the most complete review of the technological developments in this field. 
necessary to incarcerate those who, because they once committed an offense with police cognizance, have committed or will commit crimes which otherwise escape police detection.

Harassment characteristically involves the badgering of certain "offenders" by the police in temporarily detaining or arresting them without an intention to prosecute. ${ }^{12}$ Harassment involves a questionable judgment: That overzealous, unconstitutional police methods, such as arrest without suspicion, "tip-overs" or illegal searches and seizures resulting in the forfeiture of prosecution, are necessary to dislocate criminal activity which would be more difficult to deter by legitimate means. ${ }^{\mathbf{1 3}}$

All three devices are also similar in their circumvention of constitutional guarantees which are triggered by the more "traditional" police methods of search and interrogation. ${ }^{14}$

But the affirmative trap has several significant tactical advantages over its alternatives. Unlike surveillance, it does not demand a sustained commitment of personnel or require the skillful use of scientific detection devices. Moreover, the police, in initiating and participating in the of-

12 Goldstein, supra note 10, at 580: "Harassment is the imposition by the police, acting under color of law, of sanctions prior to conviction as a means of ultimate punishment, rather than as a device for the invocation of criminal proceedings. Characteristic of harassment are efforts to annoy certain "offenders" both by temporarily detaining or arresting them without intention to seek prosecution and by destroying or illegally seizing their property without any intention to use it as evidence."

13 But the sole objective of harassment is not to "drive crime out of the city." An alternate goal is to get information.

14 Aside from unreasoned dictum in Banks v. United States, 249 F.2d 672, 674 (9th Cir. 1957), that entrapment is "in violation of the due process provision of the Fifth Amendment," no case has been found which holds or intimates that the defense rests upon constitutional grounds. Judge Parker in Sorrells v. United States, 57 F.2d 973, 978 (4th Cir. 1932), specifically denied that constitutional guarantees served as grounds for recognizing the defense.

The general rule is that there is no right to be free from police surveillance provided the police have reasonable grounds for believing that the law is being violated or that the defendant has committed crimes. The cases are collected in Donnelly, supra note 2, at $1096 \mathrm{n} .16,1097 \mathrm{n} .17$. This basic rule was recently affirmed in the interesting case of People v. Crowley, 193 Cal. App. 2d 310, 14 Cal. Rptr. 112 (1961). But see the recent case of Giancana v. Hoover, Civil No. 63C-1145, N.D. Ill., July 22, 1963, preliminary injunction stayed pending appeal, Hoover v. Giancana, Appeal Nos. 14271-73, 7th Cir., July 26, 1963, in which the district court enjoined the F.B.I. from a program of harassment and surveillance directed against the complainant. The restraining order was stayed pending appeal on jurisdictional grounds. The legal advantage of surveillance stems from the physical penetration requirement for an illegal search. Silverman v. United States, 365 U.S. 505 (1961). However, this advantage may soon be lost in the light of the qualifications in the majority opinion, Mr. Justice Douglas' well reasoned separate concurring opinion which argued that the physical penetration rule is an anachronism and the recent dictum in Lanza v. New York, 370 U.S. 139 (1962), to the effect that the crucial notion is privacy. If the physical penetration requirement is dropped the police may be forced to place even greater reliance on the affrmative trap. 
fense, have the opportunity to be close to the transaction at all times, and thus the risk of losing either evidence or the offender is reduced. On the other hand the device does not require the police to abandon prosecution, as does a program of harassment.

The use of the device, however, is limited by both tactical considerations and legal doctrine. Obviously, the affirmative trap is an awkward and difficult device to use in the detection of crimes of violence. And where the consent of the victim vitiates an essential element of the crime, its use immediately presents the "target" with a defense-noncommission of the crime. 15 Thus in a prosecution under a general assault statute, conviction of a defendant who put his hands on an undercover agent's privates after gestures of invitation to do so was reversed on the ground that under the assault statute "the touching of an apparently willing and competent person is not an assault."16 Similarly a prosecution for criminal fraud failed where the "victims" of the fraud were police officers who were not misled by the false statements of the accused.17

The narcotic sales statute, however, presents a perfect situation for the use of the device. Consent does not vitiate the offense. Narcotic sales often take place between two persons who are not well acquainted. Through the use of informers undercover agents can insert themselves into the transactions without arousing suspicion. As a result it is not surprising that in almost all of the recent cases where the defense of entrapment is raised, the offense with which the defendant was charged was the sale of narcotics. ${ }^{18}$ Interestingly enough, the three states with

15 Sorrells v. United States, 287 U.S. 435, 442 (1932) (dictum); Love v. People, 160 III. 501, 43 N.E. 710 (1896); State v. Nelson, 232 N.C. 602, 61 S.E.2d 626 (1950). The authorities are somewhat in conflict on this point and there is some ill reasoned opinion that passive acquiescence or even facilitation of the offense-so long as the defendant himself performs all the legally requisite acts-does not constitute consent vitiating the offense. This result is reached on the theory that consent is given only to the performance of acts necessary to expose the crime and not to the commission of the crime itself. See People v. Rodriguez, 61 Cal. App. 69, 214 Pac. 452 (1923); People v. Smith, 251 Ill. 185, 95 N.E. 1041 (1911).

10 Guarro v. United States, 237 F.2d 578 (D.C. Cir. 1956).

17 People v. Schroeder, 132 Cal. App. 2d 1, 281 P.2d 297 (1955).

18 In addition to the situational unsuitability of the device for crimes of violence and the vitiating consent problem, there are administrative considerations which restrict the use of the "controlled buy" almost exclusively to narcotic sale cases. Although the device was reported to be used occasionally to ferret out abortion and prostitution offenses, several difficulties were noted. The prostitution cases break down into three categories: First, the "street walkers," second the "B girls," and third the "call girls." Toward the street walkers the police have a general policy of laissez faire. Their feelings, corroborated by the prosecutor, are that "there are so many of these girls we don't know what to do with them. So long as they aren't 'sandbagging' anybody or operating in places where their activity is objected to, our policy is let well enough 
the biggest "narcotics problem"19 have taken distinctly variant positions as to the permissible scope of the affirmative trap. New York apparently does not recognize the defense..$^{20}$ California, on the other hand, gives the

alone. Of course if their solicitation is obvious, the street patrol officer is bound to bring them in. But he doesn't go looking." It was also mentioned that it is very difficult for an officer to make a solicitation without it looking as though he had suggested the idea to the woman. On the other hand, there is no need for the officers to solicit the " $B$ girls" for that is the very office of the "target." The tactic here is to "watch and wait" after going to the appropriate location. An affirmative trap will occasionally be laid for the "call girls." Invariably, however, the police have access to information and find the raid to be the appropriate device for penetrating the operation. But see People v. Van Scoyk, 20 Ill. 2d 232, 170 N.E.2d 151 (1960).

Three reasons appear for the restricted use of the device in abortion cases. First, the police find it difficult to obtain willing and convincing decoys. Second is the practical limitation that the prosecution must be for attempt, and this is often difficult to prove. $\mathrm{A}$ third limitation, (not explicitly recognized by the police interviewed but surmised from the attitudes expressed) is that an affirmative trap for an abortion case usually requires penetration of ostensible professional respectability.

19 One of the principal defects in most discussions of narcotics is lack of clarity as to what the "problem" actually is. Is it distribution and the concomitant wrecking of the financial structure of the community? Is it public expenditure of funds for rehabilitation? Is it the incidence of crime that is supposed to be a direct result of addiction? Is it the enraging of the moral sense of the community? Available information on the extent of "The Problem" is sparse and generally inadequate. A complete review of the statistics will not be attempted here, but the following may be taken to illustrate to some extent the recognized comparative trends.

TOTAL ADDICTS AND REPORTED VIOLATIONS

\begin{tabular}{|c|c|c|c|c|c|c|}
\hline & \multicolumn{2}{|c|}{1960} & \multicolumn{2}{|c|}{1961} & \multicolumn{2}{|c|}{1962} \\
\hline & $\begin{array}{c}\text { Total } \\
\text { Addictsa } \\
\text { Dec. } 31\end{array}$ & Violationsb & $\begin{array}{c}\text { Total } \\
\text { Addictse } \\
\text { Dec. } 31\end{array}$ & Violations & $\begin{array}{c}\text { Total } \\
\text { Addictse } \\
\text { Dec. 31 }\end{array}$ & Violationst \\
\hline New York & 20,648 & 417 & 21,813 & 416 & 22,031 & 368 \\
\hline California & 7,411 & 424 & 7,592 & 301 & 7,412 & 261 \\
\hline Illinois & 6,533 & 137 & 6,924 & 118 & 7,034 & 217 \\
\hline
\end{tabular}

a U.S. Treasury Departalent, Bureau of Narcotics, Traffic in Opium and Other Dangerous Drugs for the YeAr ENDEd December 31, 1960, p. 68, table 2 (1961).

b $I d$. at p. 69 , table 4 .

c U.S. Treasury Department, Bureau of Narcotics, Traffic in Opium and Other DANGerous DRUGS For the YeAr ENDED DeGEMber 31, 1961, p. 60, table 2 (1962).

d $I d$. at p. 62 , table 5 .

e U.S. Treasury Departinent, Bureau of Narcotics, Traffic in Opium and Other DANGerous Drugs for the YeAr ENDED December 31, 1962, p. 61, table 2 (1963).

I Id. at p. 62 , table 4.

20 People v. Schacher, 181 Misc. 769, 771, 47 N.Y.S.2d 371, 372 (Magis. Ct. 1944) (dictum): "[I]t is well settled that entrapment is not recognized as a defense in New York State." No cases were cited to support this proposition. A case that may be responsible for the belief that the defense is unavailable in New York is Board of Comm'rs of Excise v. Backus, 29 How. Pr. 33, 42 (N.Y. Sup. Ct. 1864, where the court had occasion to say in dictum: "[T]his plea has never . . . availed to shield crime ... and it is safe to say that under any code of civilized ... ethics, it never will." The nonrecognition of the defense in New York has only the status of belief since (ac- 
defense liberal recognition. ${ }^{21}$ Illinois recognizes the defense but narrowly limits its application. ${ }^{22}$

\section{Judicial Doctrine}

The Illinois cases have never adequately articulated the doctrinal foundation of the defense of entrapment. In a recent case the Illinois Supreme Court found it sufficient to observe only that it is "deeply rooted in Mllinois and federal law."'23 As a result it is necessary to turn to the federal cases for an exposition of the doctrinal foundations of the defense. The positions of the majority and minority in Sorrells $v$. United States, ${ }^{24}$ and its more recent counterpart, Sherman $v$. United States, ${ }^{25}$ illustrate the possible approaches.

In Sorrells the majority ${ }^{26}$ based the defense on congressional intent. Entrapment is established when,

the criminal design originates with the officers of the Government, and they implant in the mind of an innocent person the disposition to commit the alleged offense and induce its commission in order that they may prosecute. ${ }^{27}$

The Court justified its finding of congressional "intent" on the ground that a police device designed "to cause, to create crime in order to punish it ... is unconscionable [and] contrary to public policy." 28 In the opinion of the majority, violation of this public policy by the government warrants an exception to the general rule that instigation of a criminal offense by another will not exculpate the defendant. ${ }^{29}$ To determine whether the defendant was possessed of the requisite proclivities "the predisposition and criminal design of the defendant are relevant" and his past record and reputation are admissible in evidence. ${ }^{30}$ For the majority, police conduct must be evaluated in the light of the particular

cording to a prominent defense counsel) there is overwhelming reluctance to urge it in face of the above dicta, and, more importantly, the understanding that the defense admits the commission of the acts constituting the offense. It was also mentioned that the type of defendant against whom the device is characteristically used is prosecuted for "minor" offenses so that the "cost" of the defense is too high.

21 See People v. Benford, 51 Cal. 2d 884, 345 P.2d 928 (1959).

22 See People v. Toler, 26 Ill. 2d 100, 185 N.E.2d 874 (1962).

23 People v. Hall, 25 Ill. 2d 297, 300, 185 N.E.2d 143, 145 (1962).

24287 U.S. 435 (1932).

25356 U.S. 369 (1958).

26 Justices Hughes, Van Devanter, Sutherland, Butler and Cardozo. Mr. Chief Justice Hughes wrote the opinion.

27287 U.S. at 442.

28 Id. at 444, citing Butts v. United States, 273 Fed. 35, 38 (8țh Cir. 1921).

29 Id. at 442; see Perkins, Crimtnal Law 847-52 (1957).

30287 U.S. at $441,451-52$. 
defendant's reluctance (or willingness) to commit crime as shown by his past record and reputation. If the defendant's past conduct shows him reluctant, then it is more readily to be inferred that the "genesis of intent" was with the government.

In concurring, the minority ${ }^{31}$ explicitly rejected congressional intent as the basis of the defense. Rather, "it is the province of the court ... to protect itself and the government from such prostitution of the criminal law."32 Judicial rather than legislative integrity is at stake. For the minority the defendant is not set at liberty because the genesis of intent lay with the government, but because "reprehensible methods" 33 "ought not to be permitted by any self-respecting tribunal." 34 Police conduct is to be evaluated in the light of general standards. The record and reputation of the defendant are irrelevant and inadmissible. ${ }^{35}$ The test is not whether the conduct of the government exceeds the particular defendant's susceptibility, but whether it falls below standards which would be a "sacrifice of decency. The enforcement of this policy calls upon the court ... to appraise their [the facts'] effect upon the administration of justice."36

In Sherman ${ }^{37}$ the new Court split the same way. The majority ${ }^{38}$ again bases the defense on congressional "intent" inferred from public policy. The genesis of intent test is to be applied by means of "an appropriate and searching inquiry into [the defendant's] ... conduct and predisposition." 39

In a concurring opinion Mr. Justice Frankfurter ${ }^{40}$ expanded the position of the minority in Sorrells. The defense is based on the federal courts' "recognized jurisdiction to formulate and apply 'proper standards for the enforcement of the federal criminal law ...." 41 The minimum standards of police conduct are those "to which common feelings respond, for the proper use of governmental power." 42 Since it is "wholly irrele-

31 Justices Roberts, Brandeis and Stone. Mr. Justice Roberts wrote the opinion. Mr. Justice McReynolds dissented.

32287 U.S. at 457.

33 Id. at 453.

34 Id. at 455 .

35 Id. at 459 .

36 Id. at 455 .

37356 U.S. 369 (1958).

38 Justices Warren, Black, Burton, Clark and Whittaker. Mr. Chief Justice Warren wrote the opinion.

39356 U.S. at 373, quoting Sorrells v. United States, 287 U.S. 435, 451 (1932).

40 Justices Douglas, Harlan and Brennan joined in the opinion.

41356 U.S. at 380, citing McNabb v. United States, 318 U.S. 332, 341 (1943).

42 Id. at 382 . 
vant" to ask if the "intention ... originated with the defendant," 43 past records, conduct and reputation are inadmissible in evidence. ${ }^{44}$

The test for the minority is whether the conduct of the police will trap only those who, objectively considered, are ready and willing to commit crime.45

An early Illinois entrapment case noted a preference for the reasoning of the minority in Sorrells.46 Although succeeding cases have not shed any further light on the basis of the defense in Illinois, the genesis of intent test favored by the majority in Sorrells and Sherman now has judicial and statutory sanction in Illinois:

A person is not guilty of an offense if his conduct is incited or induced by a public officer or employee, or agent of either, for the purpose of obtaining evidence for the prosecution of such person. However, this Section is inapplicable if a public officer or employee, or agent of either, merely affords to such person the opportunity or facility for committing an offense in furtherance of a criminal purpose which such person has originated. 47

The pivotal words in the statute are "criminal purpose which such person has originated." This phrase appears to be the basis for the drafting committee's comment that "Section 7-12 states the defense in general terms in essentially the same language which the Illinois Supreme Court uses in cases citing with approval the Sorrells case." 48

The leading Illinois entrapment decision is indeed a paradigm of such language:

[E]ntrapment can exist only when the criminal intent originates in the mind of the entrapping officer, and if such intent arose in the mind of the accused, there is no entrapment . . . ${ }^{49}$

Subsequent Illinois cases are entirely consistent. Representative is the extended discussion in People v. Hall:

[W] here it appears that the officer of the law or their agents have conceived and planned a criminal offense and have incited ... the accused into committing an offense which he other-

43 Ibid.

$44 I d$. at 382 .

45 Id. at 383 .

46 In re Horowitz, 360 Ill. 313, 196 N.E. 208 (1935). The court merely noted that the minority basis was "simpler." But the court went on to formulate the standard against which police conduct should be measured in the terms of the Sorrells majority.

47 Ill. Rev. STAT. ch. 38, \& 7-12 (1961).

48 Joint Comm. to Revise the Illinois Criminal Code, Tentative final Draft of the Proposed Ilinois Revised Criminal Code of 1961, 204 (1960).

49 People v. Outten, 13 Ill. 2d 21, 23, 147 N.E.2d 284, 286 (1958). 
wise would not have committed and had no intention of committing, entrapment is established and no conviction may be had .... On the other hand, entrapment is not available as a defense to one who has the intent to commit the crime, and does so merely because an officer of the law, for the purpose of securing evidence, affords such person the opportunity to commit a criminal act, or purposely aids or encourages him in its perpetration. ${ }^{50}$

In order to determine whether or not the intent originated with the defendant the Illinois cases hold that "the predisposition and criminal design of the defendant ... [are] relevant, and the People may ... introduce such evidence relating thereto . . . "51 Characteristically this takes the form of prior convictions. For instance, in People $v$. Hall the court denied the defendant's entrapment plea, observing that "the record ... reveals . . that defendant, wise in the ways of narcotics traffic, and already once convicted of possession, was predisposed ...."52 But proof of prior convictions is not necessary in order to show that the intent originated with the accused. "[A]lthough the defendant had no prior criminal record, this factor alone cannot overcome evidence of his ability and instant willingness to make the unlawful sale as soon as the opportunity to do so was presented." 53

Two other factors serve to locate the genesis of intent in the accused: an existing course of the same or similar conduct ${ }^{54}$ and ready complaisance in the commission of the offense..$^{55}$ Did the defendant perform the solicited criminal act without hesitation, "considering the stealth and secrecy with which the traffic in narcotic drugs is carried on"?56 Did he

50 People v. Hall, 25 Ill. 2d 297, 300, 185 N.E.2d 143, 145 (1962).

51 People v. Outten, 13 Ill. 2d 21, 25, 147 N.E.2d 284, 286 (1958). See also People v. Gonzales, 25 III. 2d 235, 238, 184 N.E.2d 833, 835 (1962); People v. Wells, 25 Ill. 2d 146, 150, 182 N.E.2d 689, 692 (1962).

52 People v. Hall, 25 Ill. 2d 297, 300, 185 N.E.2d 143, 145 (1962).

53 People v. Gonzales, 25 Ill. 2d 235, 238, 184 N.E.2d 833, 834 (1962).

54 The defendant is usually characterized as "wise in the ways of narcotics traffic," People v. Hall, 25 Ill. 2d 297, 300, 185 N.E.2d 143, 145 (1962), because his "ready access to a source of narcotics drugs, together with his familiarity with the narcotics trade are completely incompatible with an otherwise innocent victim." People v. Wells, 25 Ill. 2d 146, 150, 182 N.E.2d 689, 692 (1962). See also People v. McSmith, 23 Ill. 2d 87, 95, 178 N.E.2d 641, 645 (1961). Among the earlier cases are People v. Clark, 7 Ill. 2d 163, 130 N.E.2d 195 (1955); People v. Gaugliata, 362 Ill. 427, 429, 200 N.E. 169, 170 (1936) (prosecution witness testified to the purchase of narcotics regularly from the defendant three or four months before the trap, and defendant's record confirmed this).

55 People v. Clark, 25 Ill. 2d 331, 332, 185 N.E.2d 191, 192 (1962): "All the testimony ... shows that [the officer and his agent] ... merely told the defendant they wanted to purchase narcotics and defendant agreed to sell ...." People v. Gonzales, 25 Ill. 2d 285, 184 N.E.2d 833 (1962) ("Instant willingness").

56 People v. MicSmith, 23 IIl. 2d 87, 95, 178 N.E.2d 641, 645 (1961). 
exhibit no more than "the natural caution and hesitancy than could be expected of one engaged in the illegal narcotics trade" ${ }^{57}$

The recent cases recognize four principal inducements which locate the intent in the government rather than the accused: appeals to friendship, ${ }^{58}$ sympathy, ${ }^{59}$ offers of excessive amounts of money ${ }^{60}$ and appeals to the narcotic's need. ${ }^{61}$ However, the defendant must not only show that such inducements were present, or even present in combination, ${ }^{62}$ but that "undue, prolonged or persistent pressures were executed against him, ... that the inducement was dangled in front of him"63 or that he was "played upon."64

A recent Illinois case indicates that the defense in Illinois is accorded perhaps the narrowest scope of any American jurisdiction where it is recognized. In People v. Toler ${ }^{65}$ the defendant was approached over twenty times within a short period by an informer-purchaser with pleas to buy narcotics for the "son" of a "friend" who was said to be a heavy narcotics addict with only a year to live. The defendant finally succumbed, and even though there was no monetary profit and he had no prior record, the Illinois Supreme Court sustained his conviction, denying his plea of entrapment. ${ }^{66}$

57 Id. at 94,178 N.E.2d at 645 .

58 People v. Gonzales, 25 Ill. 2d 235, 184 N.E.2d 833 (1962).

59 People v. Hall, 25 IIl. 2d 297, 185 N.E.2d 143 (1962). The informer-purchaser represented that he was an addict and that the police officer was a friend who wanted some "stuff" for "his woman" who was "sick."

60 In People v. Gonzales, 25 III. 2d 235, 184 N.E.2d 833 (1962) the contention was made that the price paid for the drugs was excessive.

61 People v. Wells, 25 Ill. 2d 146, '182 N.E.2d 689 (1962). The informer-purchaser, knowing the defendant was an addict, offered to split any narcotics the defendant could get, the informer paying the full price.

62 People v. Hall, 25 III. 2d 297, 185 N.E.2d 143 (1962) (appeal to sympathy and narcotics need); People v. Gonzales, 25 IIl. 2d 235, 184 N.E.2d 833 (1962) (offer of excessive price and appeal to friendship); People v. Wells, 25 Ill. 2d 146, 182 N.E.2d 689 (1962) (appeals to friendship and narcotics need).

63 People v. Hall, 25 Ill. 2d 297, 301, 185 N.E.2d 143, 148 (1962).

64 People v. Gonzales, 25 Ill. 2d 235, 238, 184 N.E.2d 833, 836 (1962). But if the government itself supplies the drugs purchased there is entrapment per se. People v. Strong, 21 Ill. 2d 320, 172 N.E.2d 765 (1961). Compare People v. Gray, 27 Ill. 2d 527, 190 N.E.2d $368(1963)$.

6526 Ill. $2 d$ 100, 185 N.E.2d 855 (1963).

60 This decision is the only one to split the Illinois Supreme Court on the issue of entrapment. The dissenting opinion, written by Justice Schaefer and joined in by Justice Klingbiel, placed particular emphasis on the lack of prior convictions and the repeated solicitations. The majority opinion by Justice Dailey relied upon the fact that the defendant, as the majority interpreted his actions, "had quick access to substantial quantities of narcotics," and "the elaborate system of delivery whereby the narcotics were never seen in his possession." The majority felt that these actions were "hardly compatible with naivete and innocence." 26 Ill. 2d at 102, 185 N.E.2d at 876. The present writer was informed by a Cook County State's Attorney that his fellow 
Earlier Illinois cases, some of them involving invasions of reputed professional integrity, indicated that a necessary prerequisite to the use of the device was a showing by the police of a reasonable cause to suspect the target. ${ }^{67}$ Under the recent wave of narcotics sale cases this requirement has been dropped. In the case of People $v$. Wells ${ }^{88}$ the court held that it is not a necessary prerequisite to the use of the device that either the police or the informer-purchaser have substantial reason to suspect that the defendant is guilty of the solicited offense before a trap is laid. "Dry runs" and "spot checks" are condoned.

Three issues of trial administration of the defense should also be noted: pleading, burden of proof and the function of the judge and jury. The defense need not be raised by a special plea in bar but may be raised under a general plea of not guilty. ${ }^{69}$ Entrapment is an affirmative defense under the Illinois Criminal Code which requires that:

unless the State's evidence raises the issue involving the alleged defense, the defendant, to raise the issue, must introduce some evidence thereon. ${ }^{70}$

Once such evidence has been introduced, however,

the State must sustain the burden of proving the defendant guilty beyond a reasonable doubt as to that issue [in this case entrapment] together with all the other elements of the offense..$^{71}$

While the question has never been decided in Illinois at the appellate level, the invariable practice has been to consider the defense as an issue for the jury.

\section{Polige and Prosecutor Administration}

The principal means of municipal narcotics law enforcement in the city of Chicago is the controlled buy. ${ }^{72}$ Every controlled buy harbors a potential entrapment defense, for in every case the threshold elements of the defense have been met: official solicitation to commit a crime. Within the last five years the Illinois Supreme Court has decided three

members all felt that Toler was "probably entrapped," and that the only reason he was prosecuted for sale was because he "refused to turn in his supplier."

67 E.g., In re Horowitz, 360 Ill. 313, 196 N.E. 208 (1935) (unethical practice of law); People v. Beach, 266 Ill. App. 272 (1932) (violation of the Medical Practice Act).

6825 Ill. 2d 146, 149, 182 N.E.2d 689, 691 (1962).

69 People v. Strong, 21 Ill. 2d 320, 324, 172 N.E.2d 765, 767 (1961); People v. Van Scoyk, 20 Ill. 2d 232, 235, 170 N.E.2d 151, 152 (1960); People v. Outten, 13 Ill. 2d 21, 24, 147 N.E.2d 285, 286 (1958).

70 IlL. REv. STAT. ch. 38, § 3-2(a) (1961).

71 ILl. Rev. STAT. ch. 38, § 3-2(1) (1961).

72 Roughly $80 \%$ of all the narcotics cases are sale cases and $100 \%$ of the sale cases are detected by means of the controlled buy. 
times as many cases involving an entrapment defense as it did in the previous thirty. ${ }^{73}$ Despite these facts, both police and prosecutor unequivocally state that so far as they are concerned the defense is a "dead horse." The single factor quoted by these agencies to substantiate their position is that "the law is on our side." But independent of appellate doctrine there exists at present a complex of factors in the machinery of enforcement which justifies their position and which would do so even if appellate doctrines were even more favorable to the defendant. However, these factors are not natural adaptations to a rational system of enforcement. Instead they are coincidental results of a system of selective enforcement, narrowly focused on petty suppliers and consumers. Present enforcement is like a Volpone's Mansion and its lawns are not well kept.

\section{A. Police ${ }^{74}$}

1. The Decision to Trap. Although the Lieutenant in charge of the Narcotics Section is formally recognized as having the power and authority to make the decision that the controlled buy should be the principal means of narcotics law enforcement, this policy decision has not been an entirely conscious one. When questioned as to the reasons for this policy, he stated, 'It's just been standard operating procedure. I don't know who originated it. I think it's always been this way." "Necessity" was given as the reason for its continued use. Surveillance was ruled out for a number of reasons. The Section staffs only thirty-five field officers, and the "watch and wait" tactic was said to be too taxing on the personnel resources of the Section, in contrast to the "buy and bust." The police reported that it is especially difficult to make a sale case without direct, close observation and the opportunity for immediate arrest after the completion of the transaction. Therefore co-participation is essential. The sale transaction was reported difficult to identify from a distance. And even if identifiable in a particular case, it is still difficult to prove that there has been a sale-that one party simply has not been in possession of money and the other in possession of narcotics all the while.

73 The cases are collected in 10 Ill. Drg. 80-82 (1952); ILl. DrG. 5-8 (1962 Supp.). The figures are: For the last five years, thirteen; for the previous thirty years, four. In only one of the recent cases was the defense sustained. People v. Strong, 21 Ill. 2d 320, 172 N.E.2d 765 (196I).

74 The material contained in the "police" and "prosecutor" sections is derived from a series of interviews with members of the Chicago Police Department's Narcotics Section and the Cook County State's Attorney's Office conducted for the most part in a three week period during March and April of 1963. The officers and prosecutors were interested and cooperative. Many of the ideas which are incorporated in this paper originated with them. Quotations are not verbatim but were taken down by means of the key word method. During the interview I wrote down the key words in the interviewee's statements. That evening I typed out the conversation to the best of my recollection based on the transcription. 
There is a further difficulty: the opportunity for the defendant to dispose of the narcotics or flee if he identifies the officers approaching him. This, the police reported, is the principal reason why enforcement is concentrated on sale rather than possession cases. As one officer stated:

You know it's much easier to make a sale, rather than a possession case. If a guy sees you coming at him kind of fast, he'll throw it down the sewer, up on a roof, flush it down a toilet, or if he's inside somewhere shove it up his rectum. They're [the narcotics] usually small little things, wrapped in a tin-foil about the size of a half-a-stick of chewing gum and hard to find.

Police make sale cases out of choice as well as necessity. The stiff minimum penalty ${ }^{75}$ and the unremitting nature of the sale statute in failing to distinguish between addicting and nonaddicting narcotics, as well as the amount sold and to whom, ${ }^{76}$ make the sale offense particularly attractive to the police. The threat of long imprisonment makes an offer to the arrestee "to do himself some good" a strong lever with which to pry information.

The targets of the enforcement program are in large part defined by the resources of the Section. One of the most remarkable facts about municipal narcotics law enforcement is that it seldom reaches above the "street trade," the street addict and nonaddict pusher. Although the objective is to trade information in order to reach the peddler, this is rarely achieved, and only in the most exceptional cases does municipal enforcement reach the supplier. Almost all the cases involve "nickle-dime" buys (five and ten dollars worth). It was reported that when such an offender is arrested, due to fear of bodily harm, or at the very least of "being cutoff" from his source, he will inform only on his competitors-only laterally and never vertically. The Section is rarely successful in parlaying its information up the ladder of the narcotics hierarchy. There are sharp divisions between enforcement efforts at the municipal, state and federal levels. The city agency operates from the "bottom" up with the peddler as the anticipated ceiling. The state and federal agencies, Iargely on the basis of geographical jurisdiction, operate from the "top" down. When asked if there were any effort to tie the cases together, an officer responded:

Well, if I establish good contact on a personal basis with the Feds, then we swap information sometimes. But they're a much bigger operation. And the State boys, well, if they get a case that brings them into the city, or as part of their standard city pro-

75 Ill. Rev. Stat. ch. 38, $\$ 22-40$ (1961), provides for a ten year minimum penalty. 76 The statute, for instance, does not distinguish between "hard" and "soft" narcotics, e.g., heroin and marijuana. 
gram, then they pursue it. We would have to employ a full-time staff of statisticians down here to tie in all the cases we get. But sometimes, when to any clever guy something appears obvious, like seven arrests in front of the same house, well then we tie them together and make a big arrest. ${ }^{77}$

It was in response to a comment by this writer about the narrow focus of municipal law enforcement, the limitations on developing information, the division in narcotics law enforcement on a geographical basis, and the inherent conflict involved in the trading of full enforcement for information, that one of the officers characterized the present enforcement program as "Operation Crabgrass."

It is difficult to tell whether resources influence policy, or policy dictates resources. Nevertheless, the following observations may be made. The police in the Municipal Narcotics Section have a clear perception that the "Feds do their job and we do ours," almost a "to each his own" attitude. The police feel considerable public pressure to make a "fair quota" of narcotics arrests-and the street offender at least is a typical violator. In fact the Lieutenant in charge of the Section said that the goal of municipal enforcement is "to keep the streets from turning into a jungle." This public pressure is principally communicated to the police by phone calls from the public at large. Invariably the callers provide information of only a general nature, complaining that some narcotics addicts have been eating at someone's restaurant, that someone's neighbor's son is an addict, or that "a shop-lifter who got away had a glassy look in his eyes." With such general information, the officers find it very difficult to "get themselves cut in" on the alleged transactions, or even to locate the suspects.

Several moves are being planned by the Section to extend the scope of their enforcement program. ${ }^{78}$ One plan that is presently being considered is to

77 Now that the section is concentrating its efforts on "bigger fish" more frequent duplication of federal and municipal efforts occur. The officers related one instance where undercover agents from both agencies-unknown to each other-pulled up outside a house in anticipation of a "big hit," "tripped" across one another and lost the arrest.

78 Some of these plans appear to have gone into effect. Chicago Sun Times, July 29, 1963 , p. 14, cols. 1-4: "Chicago police made a purchase of $261 / 2$ pounds of processed marijuana and promptly placed three men under arrest, Sunday. The purchase by two undercover agents was one of the biggest made in Chicago history, said Lt. Cornelius Casey, head of the narcotics section of the Vice Control Division. . . . Arrested in the police trap were Luis J. Cuello, 24, of Miami, accused of making the actual sale, and two accomplices, Julio Rodriquez, 27, of $3620 \mathrm{~W}$. Walton, and Etien Rivera, 27, of $648 \mathrm{~W}$. Grace. . . The undercover agents, who had completely won the confidence of the gang members, met with the three men at a Far North Side location. The three asked $\$ 2,000$ for the marijuana, which had a retail value of $\$ 25,000$. . . 
[T] ake one of the fancier men, get a big car with out of state plates, and let him flash a few "saw-bucks" in some of the bigger night spots, and see if he can't get himself cut in on some big sales.

Another is to increase the number of teams on night duty. At present only two or three are operating on a regular basis, although if a "day" officer gets a lead which cannot be "developed" until later in the evening or at night, he will remain with his team to follow it through. The officers reported that they suspected, and had been told, that there are some "pretty heavy deals" made at night, and plan to tap this source of violation.

The scope of present municipal enforcement is affected by the nature of the police assignment itself. All of the field officers act in an undercover capacity, assuming the various guises of addict, pimp, musician and one even a small-time pusher to university students. The thirty-five field officers work in teams of three. Almost half of them are Negro, and most of the rest are of Italian and Latin extraction with fluency in Spanish. The physical characteristics of the officers limit the roles which they can assume and the areas where they can successfully operate. One of the Negro officers reported, "You know, there's a lot of traffic going up there on ... Street. But I can't go in there. The only time I get to wear a tie is when I go to court." As a result the Section has little mobility to enforce other than against the lower class violator. ${ }^{79}$

Satisfied that the coast was clear, Cuello took one of the agents to a room in the hotel, where the $\$ 2,000$ in marked bills was paid and a suitcase containing the marijuana was turned over. Riding down in the elevator, the agent placed Cuello under arrest. Simultaneously, other police officers closed in on the parked car. The second undercover agent was arrested along with his two companions. It wasn't until these two men were taken to the West Chicago Station that they realized their companion was an undercover agent."

79 The Chicago Police Department is reported to have taken the position that narcotics traffic is a victimization of Negroes by whites. In Rooney, The Negro in Chicago: 1963 Rackets Pay Off Big-for Whites, Chicago Daily News, August 12, 1963, p. 1, col. 5-8, p. 4, col. 4-7, the following statements were attributed to Deputy Police Superintendent Joseph Morris: "The Narcotics and policy rackets in this city are very well organized. . . [Narcotics] is not as widespread across the community as policy is . . . but it is a serious police problem on two counts. There are some 6,500 addicts here in Chicago. At least 90 per cent of them are Negro. Now, a junkie will do anything to get money to feed his habit. Anything. The result is that the male addict steals. And the female addict becomes a prostitute. Our experience here indicates that probably 75 per cent of our larcenies and burglaries in Chicago are committed by addicts. [Query.] Addicts commit a smaller percentage of robberies. These junkies are spending $\$ 25$ to $\$ 100$ a day to buy heroin. . . [Query.] When they steal, a fence (receiver of stolen property) will give them 10 cents on the dollar of the value of the loot. The fence will then get rid of it at a considerable profit. . . [ [I]t is a very small number of top white syndicate mobsters who are reaping great profits. We know of instances of a hoodlum investing $\$ 5,000$ to get a couple of kilos of heroin from the 
Because the resources available to the police define their targets as the street addict and nonaddict pusher and the type of offense as the "nickledime" sale, they insure against the likelihood of entrapment. As one of the sergeants put it:

We have too many "real" cases to go out and entrap somebody. Our biggest problem is to overcome suspicion, making sure the man doesn't escape, and recovering the money. If you act too anxious, that only makes them suspicious.

The abundance of "real" cases and the absence of "priority" targets means that police tactics are designed to be more precautionary than incendiary.

In summary, as a policy decision the use of the controlled buy is only in part a response to the "necessity" growing out of the physical situation inherent in the range of possible violations. It is really part of a larger policy decision to structure enforcement along the lines of a "holding action," "to keep the streets from turning into a jungle." And this larger policy decision turns upon three factors: Response to public demands, a desire to see immediate results obtained from the resources at hand and the perception that narcotics law enforcement is somehow "platted," that each man's home is his castle. Full enforcement is consistently traded for information and enforcement against the sources of supply is abandoned for the development of "real" cases. In fact there is room to doubt whether the policy decision to use the controlled buy is really a decision at all. Instead, present enforcement methods appear to be mechanical rather than inventive responses to the range of problems which narcotics violations present.

2. The Decision to Trap: Tactics. The decision as to how, when, by whom and where to make a controlled buy is left to the field undercover agents. Typically the officers will have arrested someone as the result of a prior "controlled buy" and secured information from him of another violator of equal stature.80 The informer will then make a contact and arrange a sale. He will be searched completely for narcotics and money and then driven to the prearranged location where at least one of the undercover agents will be stationed. He will complete the transaction,

Near East. And, some of these investments have brought profits of 500 per cent of the original investment."

The FBI Uniform Crime Reports for the Untred States 1961, table 40, at 131 (1962), reports that in 1961, 39,452 burglaries, 27,678 larcenies or thefts of $\$ 50$ and over and 39,990 larcenies or thefts of under $\$ 50$ "known to the police" occurred in Chicago. This totals 107,120 offenses. Accepting the $75 \%$ estimate, the 6,500 addicts in Chicago commit 81,040 offenses a year, or 12.36 burglaries or larcenies per addict per year.

80 It was reported that almost fifty per cent of the arrestees on a narcotics sale violation either give information or agree to act as "special agenits." 
return to the car with the drugs, a field test will be run to see if they are narcotics, and then both he and the seller placed under arrest. $\$ 1$ Although this is the procedure in the majority of the cases, the police have a definite order of tactical priority which is largely in response to pressures from the prosecutor to make "cases that will stick"-cases that satisfy credibility and evidentiary requirements. Because the informerpurchaser is a particularly impeachable witness his account of the transaction is not likely to be highly persuasive to a jury. The police have established a series of tactical preferences which run approximately as follows:

(1) Have the informer "cut" the undercover agent in directly to the seller as a "friend" or "boss," and the transaction take place between the latter two parties.

(2) Have the informer make the initial buy, and "cut" the undercover agent in on subsequent transactions.

(3) Make the informer a purchaser, and have the transaction take place under the close surveillance of an undercover agent "planted" nearby.

(4) Make the informer into a purchaser and let the transaction take place in some interior location where it is not observable by the police.

This order of preference results not only from prosecutor pressure but from the undercover agents themselves who feel that they have a prestige job which requires intelligence and they do not like the possibility of being outsmarted by informer-purchasers who might "frame" a case by going into an apartment building, paying a debt with the marked money, and returning with narcotics from another party who has extended them credit. ${ }^{82}$ The undercover agents are also conscious that the informerpurchaser is an interested party whose opportunity to "do himself some good" turns upon whether he can make a buy. Thus they suspect that out of police view and control he will make overweening appeals to

81 Where a series of buys are desired (usually to build evidence of a "course of dealing" and thereby obviate any claim of entrapment) an alternative method is to proceed with the transactions without the informer-purchaser. This has the added advantage of not exposing the informer.

82 As was contended by the defendant in People v. Lynumn, 21 Inl. 2 d 63, 171 N.E.2d 17 (1960), rev'd, Lynumn v. Illinois, 372 U.S. 528 (1963). "Defendant Lynumn testified that Zeno [the informer] came to her apartment to pay her $\$ 23$ that he owed her, and $\$ 5$ extra for keeping the money so long. She denied selling or giving anything to Zeno. She testified that she said she sold the package to Zeno ... only after the police had arrested her, told her she would lose her children and her aid to dependent children, and promised leniency if she would cooperate." 21 Ill. $2 d$ at 67,171 N.E.2d at 19. The Supreme Court reversed on the grounds that the statement given to the police was coerced. 
narcotics need and play excessively on the sympathies of the seller, or to make his efforts appear more important, plead and wheedle for more narcotics than he has been given money to buy at the going rate, on the grounds that he is in need of a "big bang." It is principally in the instance of informer purchases outside the control of the undercover agents that the occasional instances of arguable entrapment under Illinois law occur. It was reported that resort to this tactic is necessary in about eighty-five per cent of the cases. The other three methods do not often present the possibility of entrapment because the police remain in control of the transaction. The appellation "controlled buy" is less likely to be a misnomer.

The "serial buy" tactic is used where the police desire to get the putative seller "in real tight" so that he is more likely to give information, or where the first sales were faulty from an evidentiary point of view. ${ }^{83}$ With the necessity of future transactions in mind, the undercover agent must be able to transport the narcotics away from the seller. Frequently the seller will demand that they be "shot up" right there. The agent must explain that they are, for example, for his "woman who is sick," or for a "friend who is 'real bad' (trying to, but cannot 'dry out')." 'The necessity for this excuse, which also qualifies as an inducement, is made more urgent by the fact that invariably the purchase is, in accord with the usual practice of the Bureau, only for a small amount, and therefore can be "shot up."

Where an "immediate bust" is desired the appeal must often be to urgent narcotics need because otherwise the seller has an opportunity to go into several stores and exchange the marked money or he may arrange delivery in such a way that he is never seen in possession. However, in most cases the officers reported that the transactions are made without much "conversation" and quite swiftly, for the police have found that desperate appeals frequently make the seller suspicious. He will think that either the potential buyer has been "turned off" by his regular supplier because he is untrustworthy, has stolen narcotics from him or he will suspect that the potential buyer is an undercover agent, and walk away, denying that he has anything to do with narcotics.

Offers to sell rather than buy narcotics were reportedly never used by the officers for two reasons. First, it is claimed that they have no access to narcotics, since those seized in a controlled buy are immediately marked, sent to the laboratory, and then destroyed under close security. Further, it was reported that they were supervised by a superior officer in accounting for the money used and the narcotics obtained. They unanimously responded that the sale of narcotics would be per se en-

83 Usually where the marked funds were disposed of by the seller before his arrest. 
trapment without more, ${ }^{84}$ and stated that this was why devious means such as "double plays" (buying from one with identified funds and then selling the same narcotics to another) were not used. The present writer was unable to obtain a full picture of the possible use of this device.

An offer to "split" where the defendant is told that if he goes to a third party and buys the agent narcotics he will be paid in kind rather than with money was thought by the officers to be entrapment. ${ }^{85}$ The officers reported that they felt that the "random solicitation" or "spot check," the attempt at a controlled buy with no information indicating that the defendant would or could sell, was also entrapment per se. ${ }^{s 6}$ The threshold of police sensitivity to the defense often appeared to be lower than that of the courts themselves. One officer was shocked to learn from the author of the decision in People $v$. Toler ${ }^{87}$ which held that twenty-one solicitations did not constitute entrapment.

The same public pressures which demand that enforcement efforts be made in the first place, combined with a natural desire on the part of the officers to compile a good record, makes the police continually conscious of the problem of obtaining not only arrests but convictions. The writer was present on two occasions when officers had lengthy discussions on how to engineer an arrest without violating search and seizure requirements. An officer who loses cases due to excesses will characteristically be asked "to find a spot somewhere else" in a "safe" place. ${ }^{88}$ If the informal sanction of transfer is inadequate, the Police Regulations provide for the formal sanctions of suspension and removal. Rule 374(8) of the Chicago Police Regulations prescribes removal of any officer who "violates any law." 89 Ironically, the police appeared to be unaware of the fact that under the Illinois Criminal Code a policeman who solicits the commission of a crime has no defense to a charge of the crime of solicitation. 90

The field officer's attitude toward his job, his expectations about the effectiveness of the program of enforcement and his conception of the

84 It is. People v. Strong, 21 Ill. 2d 320, 172 N.E.2d 765 (1961).

85 It isn't. People v. Wells, 25 Ill. 2d 146, 182 N.E.2d 689 (1962). A "split" was held to constitute entrapment in Sherman v. United States, 356 U.S. 369 (1958).

86 It isn't. People v. Wells, 25 Ill. 2d 146, 182 N.E.2d 689 (1962).

8726 Ill. 2d 100, 185 N.E.2d 874 (1963).

88 The officer who engineered the Toler case is apparently no longer with the Narcotics Section.

89 Chicago Police Regulations, rule 374(8) (1959).

90 Although it might be possible to infer a defense from an interlaced reading of the statutes for an officer who instigates a trap, such an implied defense would be contrary to the general statutory pattern. See, e.g., ILL. REv. STAT. ch. 38, § 7-5 (1961), Peace Officer's Use of Force in Making Arrest. 
role he is playing are all tempering influences on the readily presented opportunities to be overzealous in his assigned task of co-participation and solicitation to commit crime. The Narcotics Section is considered by the undercover agents to be a "special unit" where both the security and the level of expertise required are high. Secret work, requiring testimony to the officers' honesty in the form of rigid periodic security checks and a knowledge of "secret crime," has made the officers extremely "honor bound" and conscientious. Their attitude toward many of their targets is distinctly ambivalent. On the one hand they store "Iecture kits" for speeches before civic groups which may properly be called "chambers of horrors" for they include all of the supposed paraphernalia of the drug addict: Needles, burned spoons, and, somewhat anachronistically, brass knuckles and long knives. On the other hand, they expressed and showed definite sympathy for the addict who pushes simply to sustain his own addiction. This writer was told several times:

These men are sick. They've all been dried out [taken a forced cure in jail] at least once, and yet they go back. They just can't stand the terrible lives they lead, so they try to escape to another world where everything is remote, a little happy, and they can have a feeling of well-being. The addict is often involved in a series of "minor" criminal acts, like homosexuality, purse snatching, and shoplifting, but there are just as many rapes by users as non-users.

However, all of the officers felt disgust for the peddler who is not addicted. Thus the police do make a differentiation among the various types in the rather narrow category of "street offenders," and insofar as there is a "priority target" it is the nonaddict peddler. What the officers have learned themselves by their close association with the criminal offenses they are trying to control is in conflict with what the public, or their perception of what the public, demands of their efforts. Despite this tension, it distinctly appeared that the officers' own notions were often controlling, and this was especially clear in their reluctance to extend offers to sell or split or pursue random solicitations of those whom they had no reason to suspect of violation of the narcotics laws.

3. The Decision to Arrest, Book and Bring before the Prosecutor. Except for the police decision to let the defendant out on a "pass" to develop cases and information in the field, police decisions to arrest are largely routine. In no case was a seller in a "controlled buy" released on the street. The principal reason for a policy of "complete arrest" is the desire to develop information, and the police feel that this can be done only if the defendant feels that he is under a genuine threat of imprisonment. 
In addition, the arrestee usually has little conception of his rights, and so far as he can see he has either been "caught redhanded" or his arrest is just part of a pattern which has been a fact of his life. The writer was told:

Don't forget, these guys have come from families and jobs, where the idea has always been to outwit the landlord and the boss. Lots of them don't ever object to the unfairness. They don't live in worlds where you have got privacy. Crime has always been around them, and they think that sooner or later they will fall into it.

The arrestee rarely objects, and the police often do not know that anything raising the entrapment issue has taken place. Secondly, the impetus to object appears to be removed when the police offer to allow the arrestee to "do himself some good" by assisting in purchases in the hope that he may get a reduced charge, or do the same in exchange for a "pass" to work indefinitely.

The decision to book is also routine. No cases were observed where the police omitted the facts of sale from their reports in order to give the arrestee what would amount to a reduced charge.

Although the release of an arrestee on a "pass" after he has been brought to the station appears to provide an opportunity for administrative elimination of possible entrapment cases, the police unequivocally stated that such a disposition was never made because they felt that the defendant had been entrapped. Since the number and importance of the suspect's contacts in the narcotics hierarchy are not directly relevant to the defense of entrapment (except insofar as they might possibly be used to show a criminal predisposition) it is unlikely that legitimate claims of entrapment are muffled by the police decision to release the "useful" arrestee on a pass.

\section{B. Prosecutor}

1. The Decision to Prosecute. The prosecutor's decision to prosecute a case based on a controlled buy is not influenced by the existence of facts raising a possible entrapment defense. The prosecutors were in unanimous agreement that they had never heard of an instance of a refusal to prosecute because of entrapment, nor would they, it was reported, ever accede to such a plea. Two principal factors account for this refusal: the procedures by which narcotics cases are initially presented for the prosecutor's consideration and the nature of the defense.

All cases are brought to the prosecutor's office by the police in the form of investigation reports. These reports are brief elaborations of the reports handed in to the Narcotics Section after arrest. They simply 
identify the parties involved, the time and place of the controlled buy, the type of drug secured and the amount of money exchanged. Attached is a chemist's certificate as to the nature of the drug.

The first step in the trial of every narcotics case is a preliminary hearing, a bench trial, at the Narcotics Court. Two of the new State's Attorneys, usually fresh from law school, are assigned to this court exclusively. They arrive at their offices and the reports, at this stage called the "State's Attorneys' File," are lying on their desks. As one prosecutor stated:

These cases are amazingly routine ... We flip through the files, the arresting officers meet us in our offices and we ride up [one flight] to Narcotics Court. I usually say, "Usual case?" and he says, "Yeah," and then we go to trial. So there's really no opportunity to see if there are any facts which might give rise to an entrapment defense at this [first] stage [of prosecution].

Of course, the decision not to prosecute can come at any stage until a verdict is returned. Nevertheless, all of the prosecutors interviewed stated that in practice the first opportunity which they had to learn of facts which might sustain a defense of entrapment was on cross-examination of the state's witnesses at trial. This is due to several factors. Principal among them is that the defendant at preliminary hearing is sometimes unrepresented, or, more frequently, represented by the Public Defender. The Public Defender is in the same position as the prosecution with regard to notice of facts warranting an entrapment defense. He has at least as heavy a case load and sees his function as guarding against "clear" abuses of police power, such as illegal searches and coerced confessions, making the state prove its case and saving the defendant from self-incrimination. ${ }^{91}$

If the defendant is not discharged at the preliminary hearing, he is bound over to the Grand Jury on a finding of probable cause. But evi-

91 One of the prosecutors felt that the Public Defender did not often represent his client as well as he might. "I've told those guys several times that they ought to press their cases harder and not accept so many pleas." It was estimated that in over eighty per cent of the bench trials and sixty per cent of the jury trials the defendant in the typical narcotics sale case is represented by the Public Defender. It was reported by the prosecutor, and admitted by one Public Defender, that the latter's job is even more "political" than the State's Attorney's. Here, however, the method of appointment has a different impact. For while the State's Attorney is characteristically a "young man on the way up" and likely to be a relentless litigator with little motivation to weigh the full impact of his decisions in the larger context of the criminal process, the public defender is recruited from the swelled ranks of unsuccessful but campaign active local ward lawyers in their middle forties. Their observed, as well as reported, behavior was not that of the relentless litigator. At least in the typical narcotics case their efforts appear to be directed towards insuring that the immediate defendant is treated no worse than any other. 
dence presented at this hearing consists of little more than a slight elaboration of the investigation report that was in the hands of the State's Attorney in Narcotics Court.

It would seem that with such limited disclosure of the facts the entrapment defense would be an ideal surprise tactic for the defense and that therefore the prosecutor would be sure to inquire into the issue. However, sensitivity to the defense which might lead to full disclosure in the preliminary hearing, before the Grand Jury or at arraignment is low. This is due to a complex of factors.

First is the effect which police practices have on the expectations of the prosecutor about the individual case. The controlled buy is the standard detection method for narcotics sale offenses and the details of its execution are largely routine. There is nothing remarkable in the initial use of the device, and minor excesses are taken as a matter of course. An enforcement policy focused on the many "real" cases and, in the individual case, a sense of fairness resulting from the officers' perception of themselves as members of an elite are strong tempering influences on any gross abuses in the administration of the device. An extremely low incidence of police conduct which might qualify as entrapment results-a situation which would still exist even if appellate doctrine were more exacting. Consequently the prosecutor has little reason to suspect that an entrapment has taken place.

In the extraordinary case where a possible defense is present (estimated by one prosecutor to be about one in twenty) defense counsel will visit the prosecutor and argue that the charges should be dropped because the defendant was entrapped. The prosecutors never accede to this plea because of the lack of appeal the defense has to their sense of oughtness, because of their perception of their role in the criminal process, and because of their private ambitions.

It might be suspected that the resistance could be said to stem simply from the fact that "the law is on our side." But the prosecutors were found to have a distinct attitude toward the "entrapped defendant" in a narcotics sale case. They felt that his only excuse was faulty police methods, not a violation of the "letter" of the law, and the seriousness of his crime showed that he was not "innocent." While they all felt that the facts in Toler ${ }^{92}$ should have constituted entrapment, they all agreed that they would not have refused to prosecute the case unless it was shown "that the police officer twisted his [the defendant's] arm."

The first factor accounting for prosecutors' resistance to the defense is their sense of oughtness. The police object violently whenever the prosecutor reproaches them for bad practices and resent nullification

92 People v. Toler, 26 Ill. 2d 100, 185 N.E.2d 874 (1962). 
of their efforts. Second, the routine nature of the narcotics cases-typically presenting inarticulate, disengaged Negroes or shiftless Puerto Ricans or Mexicans who speak little English, all assigned to the same prosecutors before the same judge, all proceeding to the same State's Attorney, who has been presenting all cases to the Grand Jury for over forty years-has led to a routine characterization of the defendants by the prosecutor as feigning stupidity, disrespectful and sinister. The factors which may qualify the defendant as an exception because of faulty police practices, particularly excessive inducement, are not scanned. Thus, once the "offense" is "serious" enough, all of the accused are lumped together.

The second factor accounting for prosecutor resistance to the defense is their perception of the role they play in the criminal process. There was unanimous agreement among the State's Attorneys that in narcotic sale cases the jury will convict almost every time. Juries are especially unresponsive to the plea of entrapment because the defendant admits the commission of the crime and because the defendant must often take the stand to establish the facts and he "looks bad." They also agreed that the judges do not like the defense because the crime is so unpopular and the law so popular. The State's Attorneys envisage their role in the criminal process as one of full prosecution limited only by the probabilities of failure at trial.

The third factor is that the great majority of the State's Attorneys are on short political tenure and are desirous of making reputations as relentless litigators with varied trial experience. They are conscious of being "fresh" from school-often schools not among the highest ranked -and many readily expressed a desire to "compensate." The career prosecutor appeared much "mellower" and sympathetic, and confessed that if he saw a clear case of entrapment, as he felt the Toler ${ }^{93}$ case was, he would refuse to prosecute, even though he knew someone else in the office would be assigned the case and that he might possibly win it.

In summary, then, the defense of entrapment never triggers the decision not to prosecute for several reasons. On the one hand, the infrequency of police practices which would sustain the defense means that it is not an issue for which the prosecutor must remain on the alert. Second, the scantiness of the investigative report, the cursory nature of the interviewing process before trial, and the routine nature of the cases and procedure do not admit of any "danger" signals. Last, in the occasional instances when defense counsel brings such facts to light before jury trial, the prosecutor is unpersuaded because of his sense of "oughtness" based on the nature of the defense (faulty police methods), his 
expectations of the judge's and jurors' responses and his personal motivations.

2. The Decision to Charge. Until about a year ago the standing policy of the State's Attorney's office was to reduce charges in narcotics cases from sale to possession only in the most extenuating circumstances and to pursue a policy of "full prosecution." Partly as a result of the great number of acquittals that resulted, ${ }^{94}$ partly as a result of an increasing case load ${ }^{95}$ and due in large part to the judge's reluctance to apply the stiff and unremitting minimum sentence of the sale statute, the present policy is to reduce charges when it is felt that an acquittal would otherwise result.

This fact, coupled with the hardened practice of the trial judges of holding that the defense of entrapment is inconsistent with a denial of the commission of the acts asserted under a general plea of not guilty, ${ }^{96}$ has resulted in a simple accommodation which renders the defense virtually obsolete. The defendant invariably takes a reduced charge rather than risk the "all-or-nothing" defense of entrapment.

The prosecutor will reduce charges in a narcotics sale case on three principal grounds:

(1) When the defendant has given valuable information to the police, information which has led to at least several good cases.

(2) When problems of proof are presented and the prosecutor feels that he can prove possession but not sale.

(3) When there has been a "minimal" violation of only the "letter" of the law in a controlled buy.

The latter two grounds are important in this discussion, for many of the factors which there lead to a reduction in charges would support an entrapment defense.

A typical example of a case where the prosecutor will reduce a charge due to anticipated difficulty of proof is where the informer-purchaser has made the controlled buy completely out of sight of the police undercover agents. The State's Attorney must then put the informer-purchaser

94 See note 7 supra.

95 The result of more vigorous enforcement efforts.

96 This is a possible construction of the cases. In People v. Strong, 21 Ill. $2 d 320$, 324,172 N.E.2d 765, 767 (1961), the court said "It is true that the defense of entrapment presupposed a criminal offense into which the defendant was enticed, and may be therefore inconsistent with a claim of total innocence." People v. Van Scoyk, 21 Ill. 2d 232, 235, 170 N.E.2d 151, 152 (1960): “D]efendant's complete denial of any misconduct is inconsistent with the defense of entrapment . ..." People v. Outten, 13 Ill. 2d 21, 24, 147 N.E.2d 284, 286 (1958): "The defendant cannot here invoke this defense in that, at the trial, he did neither admit the unauthorized sale of the heroin to Smith, nor offer evidence to prove that he was lured. . . "But see the new Illinois Criminal Code, Ill. Rev. Stat. ch. 38, § 3-2 (1961) (Effective January 1, 1962). 
on the stand and this, it is felt, gives the defense an impeachable witness as well as "burning out" the source of information. ${ }^{97}$ In such a case the prosecutor's reduction of charges to possession eliminates the facts which might support the entrapment defense, since the informer-purchaser would have induced the sale, not the possession.

More frequent are cases of the third type. Here four factors are operative in the prosecutor's decision to reduce charges:

(1) The type of narcotics (addicting or nonaddicting, usually a question of heroin or marijuana).

(2) The amount ("pure" or "padded," "bag" or "spoon").

(3) The type of violator (prior record, addict, nonaddict).

(4) Sale to whom (person posing or known to be an addict or someone posing as a "chippy" (a novice or nontaker)).

For example, in a case of a controlled buy of two marijuana cigarettes from a person with no prior record to a known forty-five year old addict for three dollars, the defendant would receive a reduced charge from sale to possession. ${ }^{98}$ The absence of a prior record, which might lead to a reduction of charges, would also be relevant to an entrapment defense. So, too, would the role played by the undercover agent. The more realistic the claimed need for narcotics on the part of the undercover agent (as where he poses as a heavy user), the more likely it is that an entrapment has taken place.

The prosecutors unanimously stated that the single reason which leads to the reduction of charges where there is insufficient evidence or a "letter-of-the-law" violation is the anticipated adverse response of the judge to full prosecution. Although it was reported that the trial judges will sometimes reduce the charge themselves-even though formally they are bound by the crime charged in the indictment-the prosecutors stated that they never counted on this and that their judgments were made solely in view of the likelihood that the defendant would be acquitted on a verdict of not guilty because of the harsh character of the sale statute.

97 The author was told by both prosecutor and police: "You know, they [those engaged in the narcotics trade for a living] have scouts around to see who has been telling what. There are plenty of people in court who have no right to be there."

98 In the unreported case of People v. Galindo (Crim. No. 591433, Crim. Ct., Cook County, Ill., 1959), the facts were as follows: An off-duty undercover agent, on leaving a restaurant, observed a shiftless looking character of Latin appearance standing on a street corner. On an admitted chance, he approached the "suspect" and asked if he had any "stuff." The "suspect" called the officer over and sold him two marijuana cigarettes for three dollars. Defendant was charged with the sale of narcotics. The trial judge said that because the officer had no reason to suspect that the defendant was engaged in illegal activity, he would hold that there was entrapment as to the sale unless the prosecution agreed to reduce the charge, which was done. 
There is, however, an important factor leading to a reduction in charge which is unrelated to the entrapment defense: Is the defendant an addict or nonaddict? If he is shown to be a consumer of narcotics the prosecutor feels that he sells only to sustain his own addiction (taking the amount sold into consideration) and the charge will be reduced. If he is not an addict the defendant is likely to be characterized as a "nonaddict pusher" and the charge will not be reduced (although the amount of the sale and to whom-for example, an undercover agent posing as a nonuser-has a countervailing effect).

Of the factors warranting a reduction of charges in the "token" violation situation, two also support an entrapment defense: type of defendant (no prior record) and sale to whom (a known addict as opposed to a novice). As a result the prosecutor's decision to reduce charges may also operate as a silencer for arguably good claims of entrapment.

Finally, it must be noted that charges can no longer be reduced once the drug is found to be a narcotic, as opposed to a barbituate, below the two year minimum penalty of the possession statute. ${ }^{90}$ Previously, reduction was often made to "state-addict" under the Illinois statute 100 which has been declared unconstitutional by the Illinois Supreme Court. ${ }^{101}$ Several of the prosecutors stated that they felt that this fact may well provide a stimulus, the impact of which is yet to be felt, for a revival of the defense of entrapment.

\section{Administrative Recommendations}

\section{A. Police}

There are five principal factors which account for the present safeguards against the precipitation of unconscionable police solicitation to commit crime.

First is the basic background factor against which all others may be placed: the definition of the focus of enforcement as the low-level streetpeddler. Although the many "real" cases necessitate constant recourse to the device of police solicitation, they also obviate the possibility of concentration on single, selected "priority-targets."

Second is the municipal police perception of their role in the entire narcotics enforcement picture. Since "operation crabgrass" does not go beyond the street, it is unnecessary for the officers to attempt to penetrate the "legitimate" front of the distribution hierarchy.

Next, the esprit of the "special" force working in "secret" police units

99 ILL. Rev. StaT. ch. 38 , § $22-40$ (1961).

100 Ill. Rev. Stat. ch. $38, \S 22-3$ (1961).

101 People v. Davis, 27 Ill. 2d 57, 188 N.E.2d 225 (1963). 
has produced a remarkable ideal of honor and fairness in the officers' day-to-day operations.

Finally, the same public pressures which demand that enforcement efforts be made in the first place also demand that these efforts be vindicated by ultimate conviction. Although the actual inducements offered in the field are often the result of on the spot decision, the police avoid strategies such as the offer to sell and the "split" which would immediately raise the entrapment issue. Officers who prove to be chronic entrappers are likely to be transferred from the narcotics division.

Outside the administrative process there is one factor inherent in the affirmative trap itself which discourages excessive inducements. Often excessive inducements will jeopardize the trap by arousing the suspect's suspicions. The criminal suspect is likely to be wary of the device in view of its prevalent use and the skilled entrapper must tread a path between inducements sufficient to arouse the target's interest and inducements which arouse his suspicion.

Not all of these factors are "built into" every system of narcotics enforcement. The natural suspicions of the suspect will always be present. The pressure for convictions will be effective to protect against excesses so long as the courts recognize the defense. But the focus of the enforcement program appears to be changing. Nighttime enforcement and the "big-spender," both strategies under consideration by the Section, involve a shift of attention from the small time consumer and supplier to the chain of supply itself. Unquestionably the contemplated focus is desirable. In the normal distribution situation a demand must exist before a supply is profitable. Therefore, it might be reasoned, if the demand is eliminated so is the profit in supplying. But the narcotics supplier is selling a commodity which, because of addiction, creates its own demand. With this shift in the focus of enforcement efforts opportunities for abuse of the affirmative trap increase. Such an enforcement program would require: (1) Approaches to legitimate citizens on the theory that they are only "legitimized"; (2) offers of substantially greater amounts of money for larger quantities of narcotics and (3) focus on specific "priority-targets" who have been developed through patient infiltration typically achieved by sustained association and the establishment of ties of friendship. ${ }^{102}$

The necessity for the frequent use of the device of the affirmative trap is questionable. It is only because enforcement is focused on the "street

102 Infiltration can of course be used as the sole means of detection. Entrapment is then unnecessary. See, e.g., the sustained efforts at surveillance and infiltration by the Federal Bureau of Narcotics resulting in the case of United States v. Bentvena, 319 F.2d 916 (2d Cir. 1963), which involved thirteen defendants. 
offender" that widespread use of the device is necessary. ${ }^{103}$ The nature of the physical situation in which street narcotics offenses are committed, their attendant secrecy and unobtrusiveness, makes the affirmative trap the only effective means of penetration. But even at this level the device is inefficient. It was estimated that the average "controlled buy" required, at the minimum, fifty-and more closely seventy-five-man hours to engineer. The device is also inefficient in another sense. Insofar as it is used only as a means of obtaining further information it falls short of a policy of full prosecution.

Aside from inefficiency, the device involves two inherent dangers: first, the danger of entrapment itself and second, the debilitating effect it may have on law enforcement. Cases are not unknown where the informerpurchasers-necessary concomitants of the device-have introduced defendants to narcotics. ${ }^{104}$ There is always the risk of persistent appeals to sympathies of the highest order, ${ }^{105}$ or straight-forward "frame-ups." 106 The primary reason for the careful "security" check of all the officers in the Section is the constant opportunity presented to the officers, working without supervision in the field, to exert malice, prejudice and revenge towards their targets.

The question now is: Is there any method by which efficient total enforcement may be secured, the constant dangers minimized and safeguards strengthened.

Several specific administrative recommendations can be made:

(1) Increase efforts to achieve effective enforcement at all levels of the distribution system.

(2) Promote night duty details.

(3) Require complete investigative reports.

(4) Employ at least one statistician.

103 See the special concurring opinion of Weigel, J. in Matysek v. United States, 321 F.2d 246 (9th Cir. 1963): "I am constrained to add that the facts in this case are typical of an ugly pattern in so many arising under enforcement of narcotics laws which fail to get at the main roots of the evil-addiction itself and huge profits to large distributors preying upon it. Today we must affirm conviction of an addict-seller driven to make small sales to obtain the means to satisfy his habit in which he is enslaved. Tomorrow it will be an addict-buyer turned to a small seller for the same reason. Today and tomorrow, following the law, we shall be forced to convict on the basis of evidence obtained by enforcement officials using informers who are helpless victims of the habit. In cases such as this, the law compels us, it seems to me, to become part of a process of futile nibbling at the outermost fringes of the real evils and to condone methods of obtaining evidence which have no virtue save effectiveness."

104 E.g., People v. Silva, 180 F. Supp. 557 (S.D.N.Y. 1959). In Sherman v. United States, 356 U.S. 369 (1958), the informer induced the defendant, who was under treatment for addiction, to return to the habit.

105 People v. Toler, 26 Ill. 2d 100, 185 N.E.2d 874 (1962).

100 People v. Strong, 21 III. 2d 320, 172 N.E.2d 765 (1961). 
(5) Require weekly exchanges of information with other narcotics law enforcement officers.

(6) Insist that trading for information should occur only when:

a) The information leads directly to the arrest of a "superior"; or

b) To a "competitor" who immediately "flips" on a "superior."

(7) Informer-purchasers should be used only when they act under direct police supervision at all times.

(8) Conduct a continuing evaluation of police policies relating to the use of the affirmative trap including an evaluation of the necessity of its use in the enforcement of narcotics laws and the "targets" against which it is directed.

\section{B. Prosecutor}

The main defect in administration in the State's Attorney's office is insensitivity to the defense, due principally to five factors:

(1) The past relative infrequency of police conduct arguably qualifying as entrapment;

(2) The narrow scope of the defense as formulated in Illinois appellate doctrine;

(3) The meager investigative reports;

(4) The routine nature of the cases, the homogeneity of the defendants, the unvarying path which the cases follow, and the standardization of the facts due to the unvarying use of the detection device itself; and

(5) The prosecutor's conception of his job.

The factors which eliminate opportunities to recognize facts which might justify the defense should be eliminated.

This is imperative. First, because notions of equal justice are aggravated by procedures which effectively silence legitimate claims. Secondly, in view of the Criminal Code's requirement that the defense does not admit the elements of the offense ${ }^{107}$ and the proposed shift in enforcement policy to ostensibly legitimate members of the narcotics distribution system, the presently dormant defense may soon become a lively issue at trial. Prosecutors who are not appraised of a possible defense may be caught off guard.

It is recommended that:

(1) The prosecutor should receive investigative reports which disclose fully the facts of the alleged offense.

(2) The prosecution of narcotics offenses should not be conducted on a routine basis. Elimination of the special Narcotics Court should

107 See text page 149 supra and note 96 supra. 
be considered. Prosecutor assignments should be rotated more frequently.

(3) The State's Attorney's office should articulate standards for the reduction of charges and prosecutors should be required to give reasons for this action.

\section{The Courts}

Field research shows that the principal impact which trial court practices have had on the defense derives from the rule that a claim of entrapment admits all the elements of the offense. This makes an assertion of the defense a risk which defense counsel are seldom willing to take. Since the defense of entrapment can be raised on appeal without having been exclusively relied upon or pleaded at trial ${ }^{108}$ the first effective opportunity which the defendant has to assert an entrapment defense is in the supreme court. Only in the final stage of the criminal process are defense counsel free to urge the entrapment defense without hesitation. The supreme court should seize upon the first opportunity presented to make it clear to the trial courts that the new Criminal Code changes the intimations of the court's earlier opinions that a claim of entrapment admits the elements of the offense. ${ }^{109}$ Once some evidence is presented thereon, "the State must sustain the burden of proving the defendant guilty beyond a reasonable doubt as to that issue together with all other elements of the offense." 110

\section{Doctrinal Conclusions}

The positions of both the majorities and minorities in Sorrells ${ }^{111}$ and Sherman ${ }^{112}$ can be subjected to telling criticism.

To base the defense of entrapment in legislative intent is to conceal under the guise of statutory interpretation a process of judicial law making. As Mr. Justice Frankfurter noted in Sherman:

$[T]$ he only legislative intention . . . that can . . . be extracted from the statute is the intention to make criminal precisely the conduct in which the defendant has engaged.113

108 People v. Strong, 21 Mll. 2d 320, 324, 172 N.E.2d 765, 767 (1961): “The People insist that the defense of entrapment was not raised during the trial and cannot therefore be raised on appeal. This argument is not well taken, because facts suggesting entrapment were presented in detail and defense counsel raised the point in his closing argument. Entrapment need not be specially pleaded or relied upon conclusively so long as it has been clearly suggested in the trial court."

109 See note 96 supra.

110 ILL. REv. Stat. ch. 38, § 3-2(b) (1961). (Emphasis added.)

111 Sorrells v. United States, 287 U.S. 435 (1932).

112 Sherman v. United States, 356 U.S. 369 (1958).

113 Id. at 379 . 
The problem for the courts is not to divine legislative intent but to fill out the legislative pattern by articulating general standards for the application of the defense in situations beyond the legislative view. But the majority did not articulate standards of general application. Instead they articulated a standard based on the particular proclivities of the particular defendant. Their genesis of intent test is based on a misunderstanding of general principles of criminal liability and results in an unequal and unjustifiable treatment of the citizenry. It is clear that in every instance of police solicitation, no matter how persuasive the inducement, the defendant intended in the only sense that the law requires to commit the particular crime for which he is charged. The fact that the defendant was induced by a government agent does not vitiate his intent any more than if he were induced by a private citizen. That the intent did not originate with the defendant does not make his intent any less criminal.114

Under the genesis of intent test, the defendant's prior convictions, record of offenses for which he was not prosecuted or convicted and reputation are admissible in evidence to show that he was "predisposed" to commit the crime. But such evidence is not probative of the defendant's intent to commit the particular crime with which he is charged. Because the defendant's prior record is considered relevant, the majority position allows the police to use greater inducements against those who can be shown to have previously engaged in the criminal activity. This cannot be justified by the reason for which we allow the police to trap in the first instance: that some criminal activity is virtually impossible to detect without police participation in the offense. One who is predisposed to commit the offense obviously does not require a greater inducement than one who has a normal resistance to criminal temptations. The attempted justification for the use of extraordinary inducements against those who are shown to be "predisposed" rests on the questionable inference that although the police have used inducements strong enough to overcome the resistance of those who do not commit crimes, the defendant would have succumbed to a lesser inducement since he had the demonstrable predisposition to commit the crime. In other words, that part of the inducement which was excessive by ordinary standards is to be discounted because, it is said, the defendant would have succumbed to a lesser one.

The prejudicial impact of the defendant's prior record and reputation

114 At least one court has recognized this anomaly in the genesis of intent theory. People v. Benford, 53 Cal. 2d 1, 10, 345 P.2d 928, 934 (1959). See also Sherman v. United States, 356 U.S. 369, 382 (1958) (Frankfurter, J., concurring). But where the substantive definition of the crime requires a nonconsenting victim, no offense is committed because the trapper encouraged the target. See discussion p. 142 supra. 
is felt not only in jury deliberations but also in appellate court decisions. Ambiguities in the circumstances surrounding the crime tend to be consistently resolved against the defendant when they are wrenched out of focus by evidence of his criminal record. The reluctance of the defendant is seen as the natural reluctance of the criminal instead of the resistance of the law abiding citizen. The delay in commission is attributed to the stealth and secrecy of the criminal instead of to the difficulty which the ordinary citizen might be expected to have in gaining access to criminal means. Under the pervasive influence of a criminal record the very factors which might lead to the acquittal of a first-offender are turned against the defendant. 115

To allow the police to use stronger inducements against those who have bad reputations "in effect ... permits the police to obtain a conviction of a once rehabilitated criminal whom they have badgered into resumption of crime."116 Such practices are repugnant to our sense of fairness and equality before the law. To permit this discrimination militates against "the whole ameliorative hopes of modern penology."117 In essence the genesis of intent test makes the weakness of the defendant a crime in itself. A higher not a lower standard is demanded of those least able to comply with the demands of the criminal law.

The minority position in Sorrells and Sherman is based on questionable assumptions about the role of the judiciary in the administration of criminal justice. Although there is de facto legal authority for the power of the federal courts to supervise the administration of criminal justice, ${ }^{118}$ it is ironic but true that the courts are not in the best possible position to either protect their own integrity or insure adequate standards. A court's authority can only be felt after the fact of police excesses. Although the possibility of unsuccessful prosecutions is of concern to the police, the excessive inducements which trigger the defense are often made in spontaneous field situations. And in refusing to consider the particular defendant's record the minority casts aside one factor which normally might be thought relevant to objective standards of police conduct. Within absolute limits are not the police justified in

115 Access to narcotics is not inconsistent with a claim of innocence among certain social groups. "That he [defendant] was able to secure the drug is not in itself startling. There are doubtlessly many people who live on the seamy side of life in the great cities, innocent of association with crime and without criminal proclivities who, nevertheless, in their lives and experience about the streets have a pretty good idea of where narcotics are to be obtained." Morei v. United States, 127 F.2d 827, 834 (6th Cir. 1942).

116 People v. Benford, 53 Cal. 2d 1, 11 n.4, 345 P.2d 928, 935 n.4 (1959).

117 Sherman v. United States, 356 U.S. 369, 383 (1958).

118 McNabb v. United States, 318 U.S. 332 (1943). 
concentrating their enforcement efforts against those who in the past have shown a proclivity to commit crime?

In spite of the fact that it is possible to find fault with either position, both the majority and minority were responsive to central considerations. In asking: "Should this defendant be put in jail?" the majority attempted to articulate standards of criminal liability. In asking: "Did the police conduct violate acceptable standards?" the minority attempted to delineate the acceptable limits of the device. But in formulating general standards of criminal liability in terms of a subjective genesis of intent test the majority went astray. Curiously their question might have been better answered had they adopted the minority's objective standard. The minority, by refusing to consider the prior record of the defendant at all, turned its back on at least one factor which might be considered relevant to police conduct. Their question might have been better answered had they listened more sympathetically to the majority's subjective standards. But even though the answers are not entirely satisfactory, the questions are helpful.

As has already been noted, general principles of criminal liability demand that the victim of an affirmative trap be found guilty. Even where there has been an entrapment the victim has committed all the acts essential to the crime and with the requisite intent, namely, that the forbidden act be done. Similarly the police officer who solicits the offense is guilty. If a person solicits another to commit an offense he is guilty of solicitation if the crime is not committed and as an accessory or principal if it is committed. ${ }^{119}$

But even though under general principles of criminal liability the victim is guilty, it can be argued that to imprison such a defendant is not consonant with the deterrent aims of the criminal law. The simplest way to deter crime which is the result of police solicitation, it could be argued, is to stop the police from soliciting. The state, having been the cause of the criminal act, is hardly in a position to demand that the victim should now be imprisoned in order to protect the state against the commission of similar crimes. As in equity, the prosecution must have clean hands before relief will be granted. Under this argument every victim of police solicitation would have a good defense.

The acceptance of the device of the affirmative trap and recognition of its concomitant limitation-the entrapment defense-is based on a compromise between these two positions. The device will be accepted so long as its use can be shown to be necessary for effective enforcement of the law. The state is permitted to solicit the crime in the particular case

119 Mikell, The Doctrine of Entrapment in the Federal Courts, 90 U. PA. L. REv. 245, 264 (1942). See ILL. REv. STAT. ch. 38, §§ 5-2, 8-1 (1961). 
in the hope that the successful detection and prosecution will act to deter future violations. Field research indicates that so long as it is deemed necessary to apply criminal sanctions against consenting and competent parties engaged in selling and buying narcotics, it will be necessary to employ the device of the affirmative trap in order to detect violators. But the use of the device as a detection measure can only be justified on the basis of the unusual presumption that those who have once committed crime with police solicitation have committed or will commit similar crimes that escape police detection. Yet to abandon the device is to render the narcotics laws nugatory. Dead letter statutes should not be countenanced. The burden of this argument is not to weigh the objections to the necessary enforcement measures against the necessity of having the law, ${ }^{120}$ but to determine what devices exceed the necessities of enforcement and to provide safeguards against these abuses.

In summary, the use of the device is justified only where: (1) It is necessary for effective enforcement and (2) it can properly be implied from the conduct of the defendant that he has or would have committed similar crimes.

The element of necessity involves two factors. First, is the use of the device necessary in order to enforce the particular law involved? Second, was it necessary to use the affirmative trap device against the particular defendant? The first, it is submitted, is not a question suitable for judicial cognizance. Its solution turns on difficult choices between numerous possible police strategies for enforcement of the law. A decision to use the affirmative trap as a detection measure must rest upon a full appreciation of the day-to-day workings and limitations of crime detection. The frequency of the crime and its threat to the community must be evaluated and the difficulty of using other methods of detection weighed. This is a decision best left to the police administrative process.

The justification for using the device against the particular defendant, however, is a different matter. If the police had no reasonable cause to suspect that the defendant was participating in a continuing course of criminal conduct it is difficult to relate such "shot in the dark" traps to any rational program of enforcement. There is no reason to allow the police, without antecedent justification, to add to the temptations to crime which exist independently in society. Spot traps represent a heavy commitment of police resources with little likelihood of success. In the absence of a reasonable cause requirement affirmative traps motivated by police vindictiveness are condoned. A reasonable cause requirement has traditionally been considered suitable for judicial determination. The fact that reasonable cause requirements are more often associated

120 But see Solomon, Book Review, 30 U. CHI. L. REv. 794 (1963). 
with rights of constitutional origin should not preclude its application to the nonconstitutional right "not to be entrapped." 121 Field research has shown that the police administrative decision most readily subject to control is not the decision as to what inducements should be offered -often made in a spontaneous field situation-but whether to lay the affirmative trap at all. A reasonable cause requirement provides the courts with an effective test for supervising police conduct and turns on a concept which they are competent to handle.

The issue of reasonable cause should be tried to the judge, not the jury. The defendant's criminal record should not be allowed to infect the jury's deliberations. Because of their day-to-day familiarity with the criminal process trial judges are in a better position than jurors to evaluate police conduct. Articulated judicial decisions would give the police more effective guidelines to future conduct than would jury determinations immersed in the ambiguous mass of a general verdict.

The second important factor necessary to justify the use of the device -whether or not it can properly be implied from the conduct of the defendant that he has or would have committed similar crimes-turns on the nature of the inducements offered. If the defendant yielded to inducements which would have caused an ordinary citizen to commit the crime, then it is difficult to infer that he would have committed the crime without the inducements. Presumably, ordinary citizens do not normally commit crime. If the inducements offered by the police exceed the level of susceptibility of the ordinary citizen then the device is ineffective as a detection measure. A test responsive to these considerations is contained in the Model Penal Code.122 The thrust of the Model

121 In Whiting v. United States, 321 F.2d 72 (1st Cir. 1963), the defendant contended that a controlled buy without "prior good reason to suspect guilt" was entrapment per se. "We do not agree. Solicitation to commit a crime does not of itself involve constitutional rights and is not comparable to the arrest of person or to the invasion of premises." Id. at 76. The source of the right not to be entrapped-rhether constitutional, legislative or judicial-should be treated as unrelated to the question of its proper scope.

122 MOder PENAL CoDE § 2.13(1)(b) (Proposed Official Draft, 1962): “A public law enforcement official or a person acting in cooperation with such an official perpetrates an entrapment if for the purpose of obtaining evidence of the commission of an offense, he induces or encourages another person to engage in conduct constituting such offense by .... employing methods of persuasion or inducement which create a substantial risk that such an offense will be committed by persons other than those who are ready to commit it." The central concept in the code test is "persons ready to commit it" rather than "ordinary citizen." This leads the drafters into difficulty. Even a man of marked criminal proclivities is probably not "ready" to commit a crime of violence while an ordinary citizen, on the other hand, could probably never be induced to commit a crime of violence. As a result the drafters provided in § 2.13(3): "The defense afforded by this Section is unavailable when causing or threatening bodily injury is an element of the offense charged and the prosecution is based on conduct causing or threatening such injury to a person other than the person 
Penal Code test, in the eyes of the drafters and of Mr. Justice Frankfurter, from whose concurring opinion in Sherman it was largely taken, is in controlling police conduct. But field research has shown that the controllable police decision is whether or not to entrap at all. The actual inducements offered often turn on split second judgments made in field situations. The test is necessary because if the inducements offered exceed the susceptibility of the ordinary citizen-defined in part as a person who is not ready to commit crime-then the defendant's acquiescence does not mark him as criminal. Needless to say, such a test would encourage the police-under pressure to obtain at least an adequate quota of convictions-to use inducements which will permit conviction. But the situation surrounding the affirmative trap is often a more effective protection against excessive inducements. To succeed in trapping a suspect the police must be careful not to arouse suspicion. Excessive inducements are themselves the best way to put a suspect on guard that there is something unusual about the transaction. While many strategies-such as an offer to sell instead of to buy-raise the excessive inducement problem without creating suspicion, more often than not caution is necessary for police success. The test is, of course, important in delineating the permissible range of police conduct. But its even greater significance is in response to the question: Is this defendant criminal?

The "ordinary man" standard, turning on a judgment about the response of men not "ready" to commit crime to police inducements, is a suitable issue for jury determination. It presents an issue properly, if

perpetrating the entrapment." The reason given for this section is that "a person who can be persuaded to cause such injury presents a danger that the public cannot safely disregard." Model Penal Code $\$ 2.10$, comment 7 (Tent. Draft No. 9, 1959). But if the police have in fact offered inducements which create a substantial risk that an ordinary citizen would commit the crime, then it would appear that the police, not their target, present "a danger that the public cannot safely disregard." If the jury finds that the inducements offered created a substantial risk that an ordinary citizen would have committed the crime then there is no reason to infer that the defendant will commit or has committed similar offenses-even if the crime induced caused or threatened bodily injury to a third person. The police, rather than the defendant, having created such a risk should be held responsible for it.

The Model Penal Code supplies an additional test. Section 2.13(1)(a) provides for exculpation when the officer induces the defendant to commit the crime by "making knowingly false representations designed to induce the belief that such conduct is not prohibited." It is submitted that this test is actually only one aspect of the substantial risk test. One way in which a public law enforcement official can induce a citizen to commit a crime is to convince him that the acts induced are not criminal. But it would be perfectly natural for an agent in his undercover role to make some remark to the effect that "it isn't really criminal to sell narcotics." This should not vitiate the trap. If the officer relies upon his badge of authority, however, to convince the target that the acts are not criminal then the "ordinary citizen" test has probably been satisfied. 
not constitutionally, within the province of the jury: the guilt of the defendant.

The criminal liability of the police officer or his agent carrying out an affirmative trap has been largely ignored. One writer has suggested that the answer to the whole entrapment problem is to prosecute the entrapping officer. ${ }^{123}$ Although under present law the officer may very well be criminally liable not only when he entraps, but when he simply traps, a suspect, ${ }^{124}$ there is little reason to think that prosecutions of the police will ever occur in view of the close association between the prosecutor's office and the police. ${ }^{125}$ Hand in hand with a consideration of the entrapment defense must go consideration of the permissible scope of the now implicit state solicitation defense. ${ }^{126}$ Continuing dead letter violations of the law by the police can hardly be expected to foster a high respect for the law on their part. Yet the police are the very group entrusted with the high responsibility of front line law enforcement. Although an interlaced reading of the Illinois solicitation, narcotics and entrapment sections might result in a principle of justification for an officer or agent-informer who traps a suspect, it is impossible to infer a defense for an officer who oversteps the limits of the entrapment defense. The defense of the officer or his agent-informer should not turn on the inducements offered. Once authorized by the state to trap, it seems undesirable to put him in jail because he has, in a sense, done his job too well. Administrative transfers or suspensions combined with a loss of the conviction are the proper way to handle such overzealousness. But police officers who initiate traps on the basis of personal whim or to carry out personal vendettas, or informers who initiate traps simultaneously to placate the police and "get" an enemy, without reasonable grounds of suspicion, should be subject to criminal penalties. The first line of deterrence would be the "reasonable cause" standard of the entrapment defense itself. But an officer should not be made criminally liable because he misjudged the existence of reasonable cause. The

123 Mikell, supra note 119, at 264: "A few such convictions and the practice of entrapment would cease."

124 Since there is no explicit defense in the Illinois Criminal Code. But the reported cases attune the criminal liability of the trapper to whether or not there was entrap. ment. Reigan v. People, 120 Colo. 472, 210 P.2d 991 (1949); Wilson v. People, 103 Colo. 441, 87 P.2d 5 (1939); State v. Bigley, 53 Idaho 636, 26 P.2d 375 (1933); State v. Torphy, 78 Mo. App. 206 (1899). Cf. Lilly v. West Virginia, 29 F.2d 61 (4th Cir. 1928), holding that police pursuing criminals are exempt from traffic regulations.

125 Model Penal Code, § 2.10, comment 1 n.2 (Tent. Draft No. 9, 1959): "There is little reason to suppose that prosecutors would move against the police save in the most extreme cases." Cf. Comment, Private Prosecution: A Remedy for District Attorney's Unwarranted Inaction, 65 YALE L.J. 209 (1955).

126 See notes 90,124 supra. 
standard for the criminal liability of an officer and his agent-informer should be the lesser one of reasonable suspicion. An officer or agentinformer who initiates a trap without a reasonable suspicion that the target has engaged in similar criminal conduct can only be acting from personal motives and his activity has no relationship to the law enforcement objectives of the state.

The present Illinois rule which puts the burden of proof on the prosecution to prove the absence of entrapment beyond a reasonable doubt once some evidence has been introduced thereon should be continued. The Model Penal Code places the burden on the defendant to show "by a preponderance of evidence that his conduct occurred in response to an entrapment." 127 The reason given is that

[T] he defense of entrapment does not negative an element of the crime .... The defense does not assert that the defendant has not engaged in criminal activity nor does it truly seek to excuse or justify a criminal act. The defense is, in fact, a complaint by the accused against the state for employing a certain kind of unsavory enforcement. The accused is asking to be relieved of the consequences of his guilt by objecting to police tactics. He is a plaintiff and should be required to come forward with the evidence and to establish the main elements of his claim by a preponderance of proof. ${ }^{128}$

The answer to the above argument is that the substantial risk test not only serves to define the proper scope of police conduct but is also responsive to the question of whether the defendant's conduct justifies the application of criminal sanctions. But it is more meaningful to discuss the burden of proof standard in terms of the effect it will have on the substantive reach of the defense. In most of the cases the entrapment issue at trial turns, if raised, on a battle of credibility between an informer-agent and the defendant. If any burden of proof is placed on the defendant he will have to take the stand to rebut the testimony of the agent-informer. His past criminal record will then come in for purposes of impeachment. On the other hand, if the burden of proof is on the state the defense can attack the credibility of the agent-informer by means of his past criminal record and by exploring his relationships with the police. Because of the prevailing jury attitude towards narcotics offenders and the "caught him in the act" nature of cases made by means of an affirmative trap the usually indigent narcotics defendant is faced with a difficult burden. To put the burden of proof on him to show by a preponderance of evidence that he was entrapped

127 Model Penal Code § 2.13(2) (Proposed Official Draft, 1962). 128 Model Penal Code $\$ 2.10$ comment 4 (Tent. Draft No. 9, 1959). 
is practically to eliminate the defense. Criticism of the genesis of intent test because it turns in part on the criminal record of the defendant is not theoretically inconsistent with an allocation of the burden of proof which forces the defendant to take the stand and make his record admissible for purposes of impeachment. But in either case the jury learns of the defendant's criminal record with its presumably prejudicial impact. Putting the burden of proof on the state encourages the police to use strategies where the transaction occurs within the view of the undercover agent because an officer is not as easy to impeach as an agentinformer. This would serve to decrease the possibility of entrapment by a desperate, unsupervised informer eager to escape a jail sentence.

\section{Proposed Legislation}

The following statute is submitted as the most reasonable formulation of the principles and findings which have been the burden of this paper.

\section{Entrapment}

(1) A person prosecuted for an offense shall be acquitted if a public law enforcement official or a person acting in co-operation with such official for the purpose of obtaining evidence of the commission of such offense

(a) induces the commission of such offense by employing methods of persuasion which create a substantial risk that such offense will be committed by an ordinary citizen; or

(b) solicits the commission of such offense without reasonable cause to believe that such person has committed or will commit it.

(2) The issue in clause (1)(a) shall be tried by the jury. The issue in clause (1)(b) by the judge.

(3) Entrapment is an affirmative defense..$^{129}$

\section{State Solicitation}

(1) A public law enforcement official or a person acting in co-operation with such official shall be acquitted of the crime of solicitation or of any criminal offense committed in the course of inducing the commission of an offense by another for the purpose of obtaining evidence of the commission of the offense unless he solicits the commission of such offense

(a) without a reasonable suspicion that such person has committed or will commit it; or

129 As defined in the Illinois Criminal Code. Ill. Rev. Stat. ch. 38, § 3-2 (1961). 
(b) in such a manner as to endanger the person or property of a third person. ${ }^{130}$

(2) State solicitation is an affirmative defense. ${ }^{131}$

130 Sanction of the affirmative trap results from a delicate balance between the social interest in effective enforcement and the undesirability of police solicitation of criminal acts. When the interests of a third person are added to the formula the scales are thrown towards non-recognition of the device. See discussion note 122 supra.

131 There are no compelling arguments for making the defense affirmative. It is made affirmative here in accordance with the general scheme of the Illinois Criminal Code. 